\title{
The Effect of Environment on the Stress Corrosion Cracking of Incoloy 800
}

\begin{abstract}
ALICE DINU*
Technologies for Nuclear Energy State Owned Company (RATEN), 1 Campului Str., 115400, Mioveni, Romania

This paper studies the stress corrosion cracking (SCC) behaviour of Incoloy 800 in pure $10 \% \mathrm{NaOH}$ and, respectively, $10 \% \mathrm{NaOH}+0.33 \mathrm{~g} / \mathrm{NaCl}$ solutions. Notched and un-notched $\mathrm{C}$-ring specimens were tested in a static autoclave at $260^{\circ} \mathrm{C}$ and 50 bars. To evaluate the electrochemical behaviour of different metal/environment systems, the most important electrochemical parameters were calculated from polarization curves recorded between (-800)mVvsSCE and $(+1200) \mathrm{mVvsSCE}$ (scan rate $1 \mathrm{mV} / \mathrm{s}$ ), at $85^{\circ} \mathrm{C}$. It was emphasised that the presence of $\mathrm{Cl}$ - in caustic environment conducts to the decreasing of corrosion rate and corrosion current. Optical microscopy (OM) and scanning electron microscopy (SEM) revealed that the initiation mechanism and penetration depth of SCC cracks depend on the composition of the testing solution: in pure caustic solution, the SCC initiation is transgranular the SCC cracks propagated up to $120 \mu \mathrm{m}$, while in the presence of the $\mathrm{Cl}$, the SCC cracks started from the pits formed on the samples

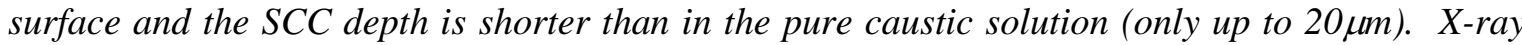
diffraction (XRD) and energy dispersive X-ray spectroscopy (EDS) analyses were used to identify the composition of the oxide layer build-up on the surface of the specimens exposed in autoclaves. The results indicate that, in the presence of the $\mathrm{Cl}^{-}$anions, the spinel oxide $\mathrm{NiCr}_{2} \mathrm{O}_{4}$ is formed in a bigger amount. Due to this compound formation, a greater SCC resistance of Incoloy 800 was observed.
\end{abstract}

Keywords: Stress corrosion cracking; Incoloy-800 alloy; CANDU steam generator

Incoloy 800 alloys have a very good resistance at corrosion in aggressive environments at an elevated temperature due to the protective oxide layer, adherent and compact, which was formed under these conditions. This behaviour can be explained by the formation of spineless oxides such as $\mathrm{FeCr}_{2} \mathrm{O}_{4}, \mathrm{Fe}_{2} \mathrm{NiO}_{4}$ and $\mathrm{NiCr}_{2} \mathrm{O}_{4}$. For this reason, Incoloy 800 was selected to be used for manufacture of the steam generator tubes in CANDU nuclear power plants. However, the problems created by the intergranular corrosion and the stress corrosion cracking could affect the structural integrity of the steam generator in the nuclear power plants worldwide.

The stress corrosion cracking requires the simultaneous action of the corrosive environment and the stress state as well. From the point of view of local chemistry, the excessive alkalinity is considerate one of the most dangerous factor that affects the initiation of stress corrosion cracking on the secondary side of the CANDU steam generators 0 . In addition, impurities such as $\mathrm{Cl}^{-}, \mathrm{Pb}$ or silicon-aluminates were found on tubes extracted from steam generators indicated 0 . Inside of crevices, impurities from cooling water (less than $1 \mathrm{ppm}$ ) by boiling can be concentrated up to $10^{3}-10^{5}$ times, forming very corrosive solutions 0,0 . The stress state appears from different reasons: the residual stresses (in expanded area of steam generator tubes at the joint with the tube sheet; the U-bend tubes, particularly in the case of small radius of curvature); the mechanical stresses that appear in the intermediate support area; the buildup of corrosive products in restricted flow areas; the thermal gradients along the steam generator tubes or alternative thermal cycles between wet zone and dry zone 0 . These contributions, taken individually, may be insignificant, but through their combined effect can reach local values that exceed the thresholds to initiate SCC.

In the context presented above, this paper brings new results concerning the initiation and propagation of SCC in the case of Incoloy-800 which has been tested in pure or contaminated with $\mathrm{Cl}^{-}$caustic environment. By electrochemical tests performed at $85^{\circ} \mathrm{C}$ the electrochemical behaviour of metal/environment system was evaluated. With the aim to simulate the SCC occurrence conditions on steam generators tubing, SCC tests in autoclaves $\left(260^{\circ} \mathrm{C}\right.$ and 50 bars) were performed. The tested specimens were examined using optical microscopy and SEM. The oxide layers formed during the tests in autoclave were investigated by XRD and EDX.

\section{Experimental part}

Materials and methods

The specimens were cut from the CANDU steam generator tubes, in their as-received state. The outer diameter of tubes is $15.9 \mathrm{~mm}$ and the wall thickness is $1.13 \mathrm{~mm}$. The chemical composition of Incoloy 800 used in experiments is

\footnotetext{
*email: alice.dinu@nuclear.ro
} 
presented in Table 1. The mechanical properties, determined in the circumferential direction of the tube, at room temperature, are given in Table 2. Figure 1 shows the microstructures of Incoloy 800 in the axial and transversal sections. The average of grains size was $11.4 \mu \mathrm{m}$ in the transversal section, and $11.2 \mu \mathrm{m}$ in the axial section of Incoloy 800 tube.

Table 1

CHEMICAL COMPOSITION OF INCOLOY-800 DETERMINED BY SUPPLIER (wt \%)

Fig. 1. Microstructure of Incoloy 800 tubes in: (a) axial direction; (b) transversal direction

\begin{tabular}{|l|c|c|c|c|c|c|c|c|c|}
\hline Fe & Ni & Cr & C & Si & S & Mn & Ti & Cu & Al \\
\hline 42.7 & 33.4 & 21.9 & 0.02 & 0.49 & 0.001 & 0.64 & 0.41 & 0.01 & 0.24 \\
\hline
\end{tabular}

Table 2

THE MECHANICAL PROPERTIES OF INCOLOY 800 IN THE CIRCUMFERENTIAL DIRECTION OF THE TUBE (ROOM TEMPERATURE)

\begin{tabular}{|c|c|c|}
\hline $\mathbf{\sigma}_{0.2 \%}(\mathbf{M P a})$ & UTS $(\mathbf{M P a})$ & Elongation (\%) \\
\hline 420 & 590 & 40 \\
\hline
\end{tabular}
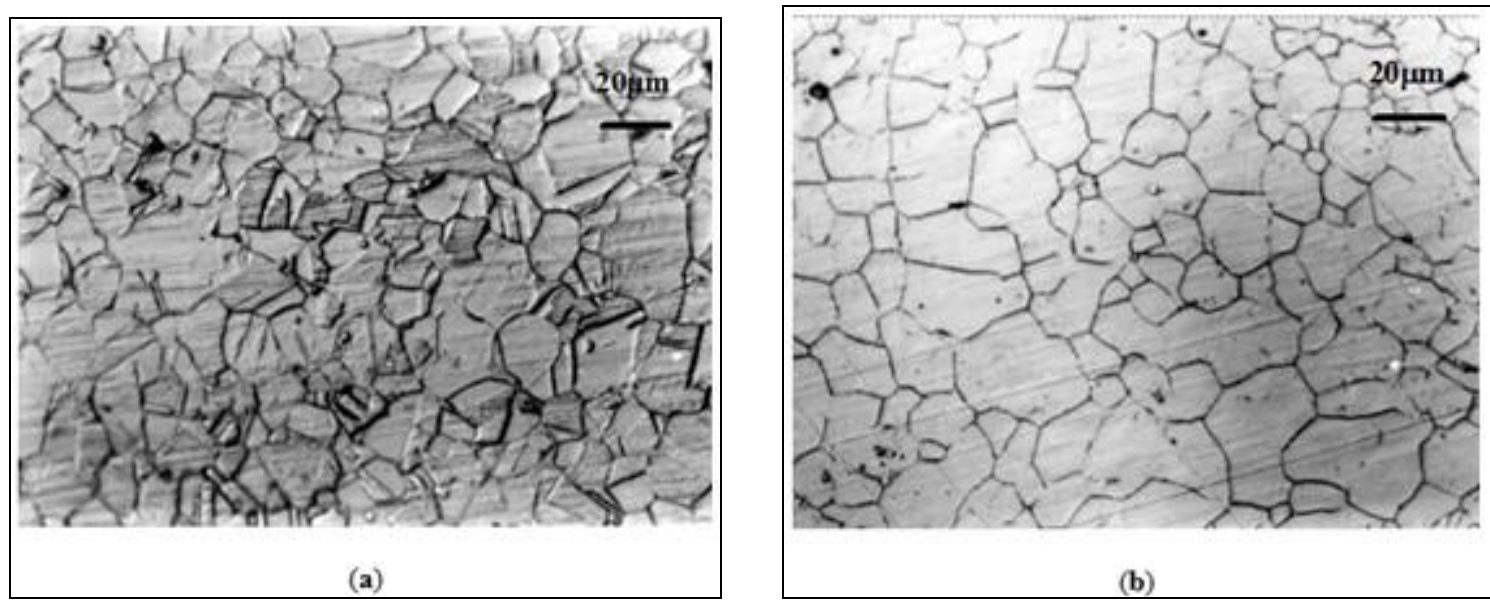

Fig. 1.Microstructure of Incoloy 800 tubes in: (a) axial direction; (b) transversal direction

The C-ring method was chosen for the loading mode of Incoloy-800 specimens 0 . The rings of $12 \mathrm{~mm}$ length were cut from the Incoloy 800 tubes. The C-rings were obtained by cutting the rings in length using an angular cutter. To obtain a stress spot in a certain zone 0 , some samples were mechanically notched. The notch had a depth of $250 \mu \mathrm{m}$ (Fig. 2a) and was obtained using a conic cutter with an angle of $60^{\circ}$. The radius at the tip of the notch is $18.5 \mu \mathrm{m}$ (Fig. 2b). The C-rings specimens were subjected of compression to a constant deformation, by using a screw. To eliminate the galvanic effects between the C-ring and screw, the screw was manufactured from Incoloy $800 \mathrm{HT}$.
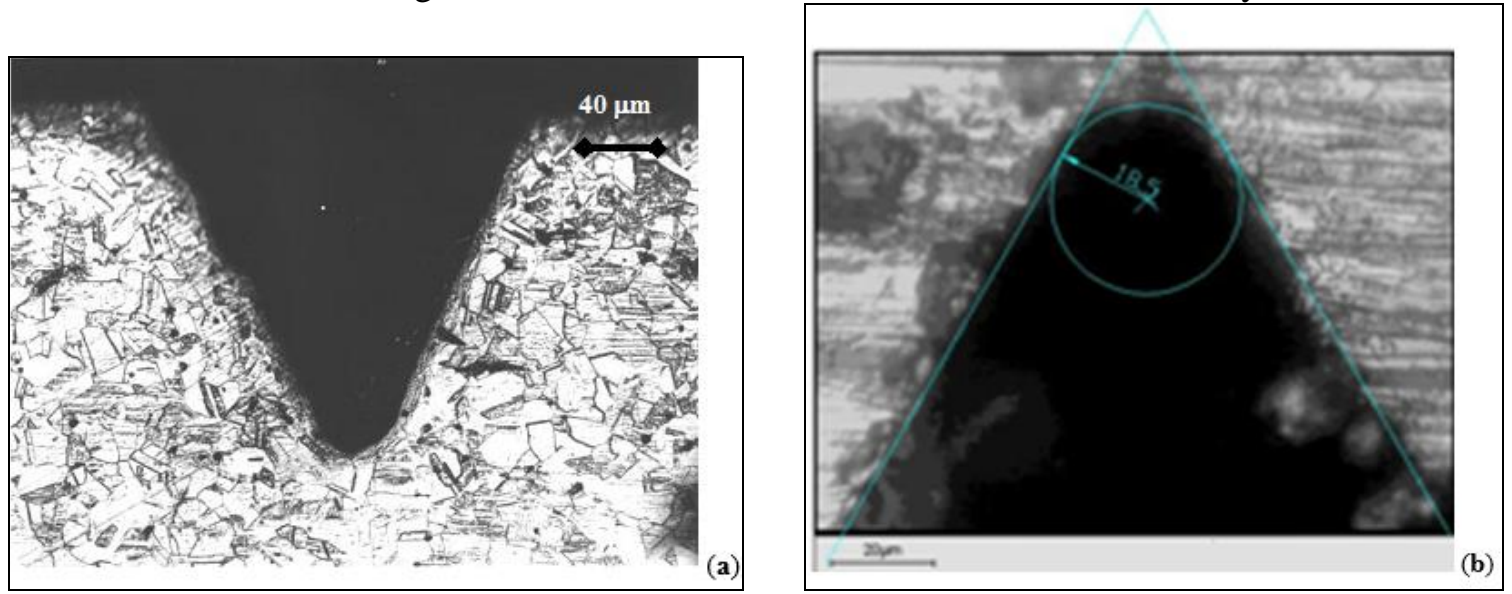

Fig. 2. Notch on the external side of C-ring: (a) transversal section; (b) radius at the highest point of the notch

For the un-notched specimens, the maximum stress was $540 \mathrm{MPa} 0$. This value is localised on the external surface of the C-ring, in the opposite site of the axial cut (Fig. 3a). In the case of notched specimens, the maximum value of the applied stress is $615 \mathrm{MPa} 0$ and is localised laterally from the notch tip (Fig. 3b). After the tightening of the C-rings at room temperature, the applied stress stabilises at a value known as the "internal stress" that is about $80 \%$ of the 
calculated value 0 . This means that the maximum values of applied stresses used in our experiments are $430 \mathrm{MPa}$, respectively 490MPa.
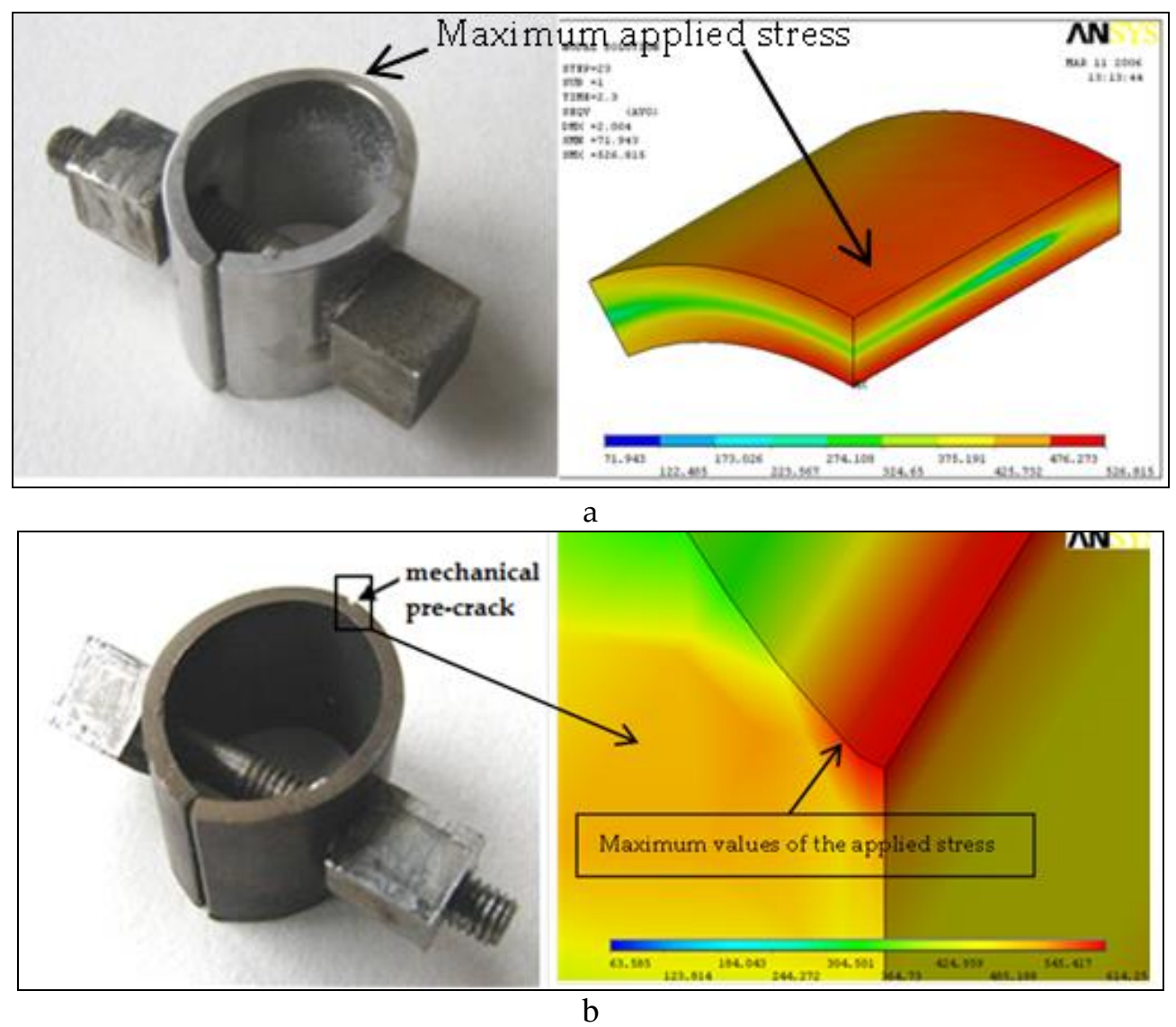

Fig. 3. The distribution of the equivalent stress for: (a) stressed C-ring without notch;

(b) stressed C-ring with notch

The SCC susceptibility tests for Incoloy- 800 were accomplished in $10 \% \mathrm{NaOH}$ pure caustic solutions $\left(\mathrm{pH}_{25}{ }^{\circ} \mathrm{C}=13\right)$ or containing $\mathrm{Cl}^{-}\left(0.33 \mathrm{~g} \mathrm{NaCl}\right.$ at $1110 \% \mathrm{NaOH}$ solution, $\left.\mathrm{pH}_{25}{ }^{\circ} \mathrm{C}=12.5\right)$. This composition of testing solutions was established taking into account the followings: the $\mathrm{NaOH}$ concentration in the crevices from the hot part of tubes can attain 3\%, even 50\% after a long period 0; the maximum allowable concentration of chloride anions in the cooling water of secondary side of CANDU reactors is less than $1 \mathrm{ppm} 0$, but, by boiling, can be concentrated inside the crevice up to $10^{5}$ times 0 .

The electrochemical corrosion tests were performed by using the Princeton Applied Research Model 273 Electrochemical System with M352 corrosion software. The tests were carried out at $85^{\circ} \mathrm{C}$, in an electrochemical cell with 3 electrodes: a working electrode with exposed area of $3.5 \mathrm{~cm}^{2}$; a reference electrode - a saturated calomel electrode (SCE); and an auxiliary graphite electrode. The polarization curves were registered in range between ($800) \mathrm{mVvsSCE}$ and $(+1200) \mathrm{mVvsSCE}$, with a scan rate of $1 \mathrm{mV} / \mathrm{s}$.

To simulate the SCC occurrence conditions in the restricted areas of CANDU steam generators tubing, the Incoloy800 stressed C-rings were tested in a Prolabo static autoclave of 1 litter at $260^{\circ} \mathrm{C}$ and a pressure of 50 bars. Because the testing environment is very aggressive, an intermediary vessel was used to introduce the testing solution $(170 \mathrm{~mL})$ and the stressed samples. The whole assembly was immersed in the autoclave containing $200 \mathrm{~mL}$ demineralised water. These quantities of solutions were chosen to assure a pressure of 50 bars, corresponding to the normal operation conditions of CANDU secondary side. The testing period was approximately 60 days.

To investigate the tested specimens, XRD, SEM, EDS and OM methods were used.

\section{Results and discussions}

Electrochemical behaviour

The electrochemical behaviour of different metal/environment systems was evaluated by calculating the most important electrochemical parameters: the corrosion current $\left(\mathrm{I}_{\text {corr }}\right)$, corrosion rate ( $\left.\mathrm{v}_{\text {corr }}\right)$ and corrosion potential $\left(\mathrm{E}_{\text {corr }}\right)$. The values obtained for the electrochemical parameters are presented in Table3. 
Table 3

ELECTROCHEMICAL PARAMETERS OBTAINED FOR THE INCOLOY 800

SPECIMENS EXPOSED IN CAUSTIC ENVIRONMENT

\begin{tabular}{|c|c|c|c|c|}
\hline Environment & Mechanical state of the sample & $\begin{array}{c}V_{\text {cor }} \\
(\mu \mathrm{m} / \mathrm{y})\end{array}$ & $\begin{array}{c}\mathbf{I}_{\text {corr }} \\
\left(\mathrm{nA} / \mathrm{cm}^{2}\right)\end{array}$ & $\begin{array}{l}\mathbf{E}_{\text {cor }} \\
(\mathrm{mV})\end{array}$ \\
\hline \multirow{2}{*}{$\begin{array}{c}10 \% \mathrm{NaOH} \\
(\mathrm{pH}=13)\end{array}$} & $\begin{array}{l}\text { un-notched; } \\
\text { maximum equivalent stress } 540 \mathrm{MPa}\end{array}$ & 126 & 11 & -500 \\
\hline & $\begin{array}{l}\text { notch with } 250 \mu \mathrm{m} \text { depth; } \\
\text { maximum equivalent stress } 615 \mathrm{MPa}\end{array}$ & 147 & 13 & -529 \\
\hline \multirow{2}{*}{$\begin{array}{c}10 \% \mathrm{NaOH}+ \\
0.33 \mathrm{~g} / 1 \mathrm{NaCl} \\
(\mathrm{pH}=12.5)\end{array}$} & $\begin{array}{l}\text { un-notched; } \\
\text { maximum equivalent stress } 540 \mathrm{MPa}\end{array}$ & 65 & 6 & -484 \\
\hline & $\begin{array}{l}\text { notch with } 250 \mu \mathrm{m} \text { depth; } \\
\text { maximum equivalent stress } 615 \mathrm{MPa}\end{array}$ & 104 & 9 & -526 \\
\hline
\end{tabular}

One may observe that the addition of $0.33 \mathrm{~g} / \mathrm{L} \mathrm{NaCl}$ doesn't change extremely the electrochemical behaviour of the stressed Incoloy 800 specimens in the caustic environment. Nevertheless, there is a slow dependence on the environment composition and on the local deformation: the presence of $\mathrm{Cl}$ - in caustic environment conducts to the decreasing of corrosion rate and corrosion current. On the other hand, the corrosion rate and the corrosion current increase with the increasing of the applied stress, while the corrosion potential shifts towards the electronegative range.

\section{SCC tests in autoclaves}

No SCC cracks on the surface of the un-notched specimens, tested in the both environments, were observed. It means that the value of applied stress of $430 \mathrm{MPa}$ is under the stress threshold of the SCC initiation in these testing conditions.

The investigation by optical microscopy in transversal section showed that the notched specimens tested in $10 \%$ $\mathrm{NaOH}$ pure solution at $260^{\circ} \mathrm{C}$, presented SCC cracks. SCC cracks are localized near the tip of the notch (Fig. 4a), where the stress and deformations had maximum values (Fig. 3b). The high value of applied stress determines the initiation of SCC cracks in several places. The maximum cracks length was maximum $120 \mu \mathrm{m}$. The metallographic images presented in Figure 4a show that both initiation and propagation of SCC cracks are transgranular. The SCC susceptibility of Incoloy 800 is diminished by the addition of $0.33 \mathrm{~g} / \mathrm{L} \mathrm{NaCl}$ in the $10 \% \mathrm{NaOH}$ solution. The optical microscopy presented in the Figure 4b shows that SCC cracks are always associated whit the presence of one pit. The maximum depth of SCC cracks was $20 \mu \mathrm{m}$. Since the SCC crack propagation speed is determined by the oxide film growth rate and its breaking period 0 , probably the stress conditions needed to break oxide film with a high enough frequency so that the crack can propagate rapidly were not fulfilled.

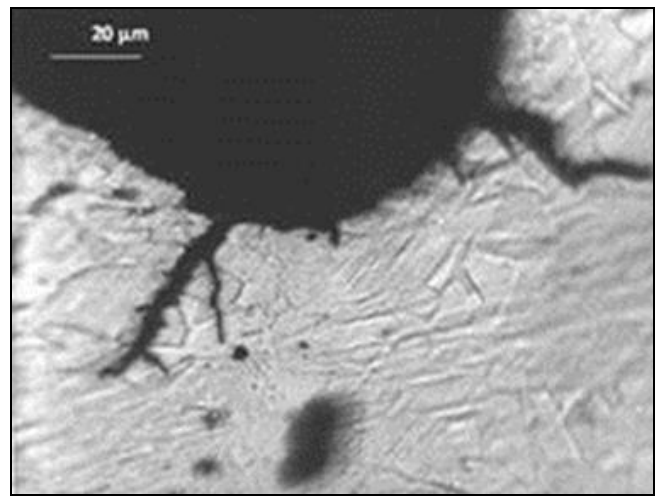

a

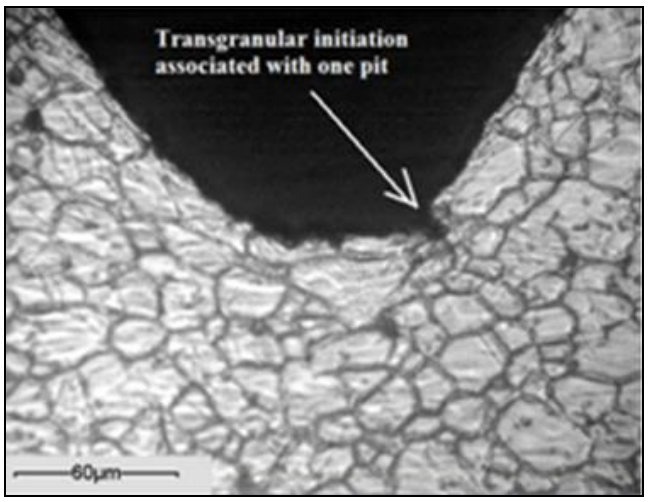

b

Fig. 4. SCC cracks obtained on stressed Incoloy 800 specimens (490MPa applied stress) tested 60 days, at $260^{\circ} \mathrm{C}$ in: (a) $10 \% \mathrm{NaOH}$; (b) $10 \% \mathrm{NaOH}+0.33 \mathrm{~g} / \mathrm{lNaCl}$

The presence of branched SCC cracks on the fracture surface of one sample tested in pure alkaline solution was put into evidence by SEM. In Figure 5a it may observe the presence of many SCC cracks. Also, the Figure 5a shows that the cracks propagate through the grains and that the propagation path has a "fan" form, specific to the transgranular propagation in the case of austenitic alloys in caustic environment 0 . In the presence of Cl- anions, SCC cracks are associated with pits (Fig. 5b). It may observe that the SCC cracks are initiated from one pit. Taking into account these results, we can say that the pits formed in the crevice where is a complex corrosive environment (not only caustic) act as initiating places for SCC cracks. 

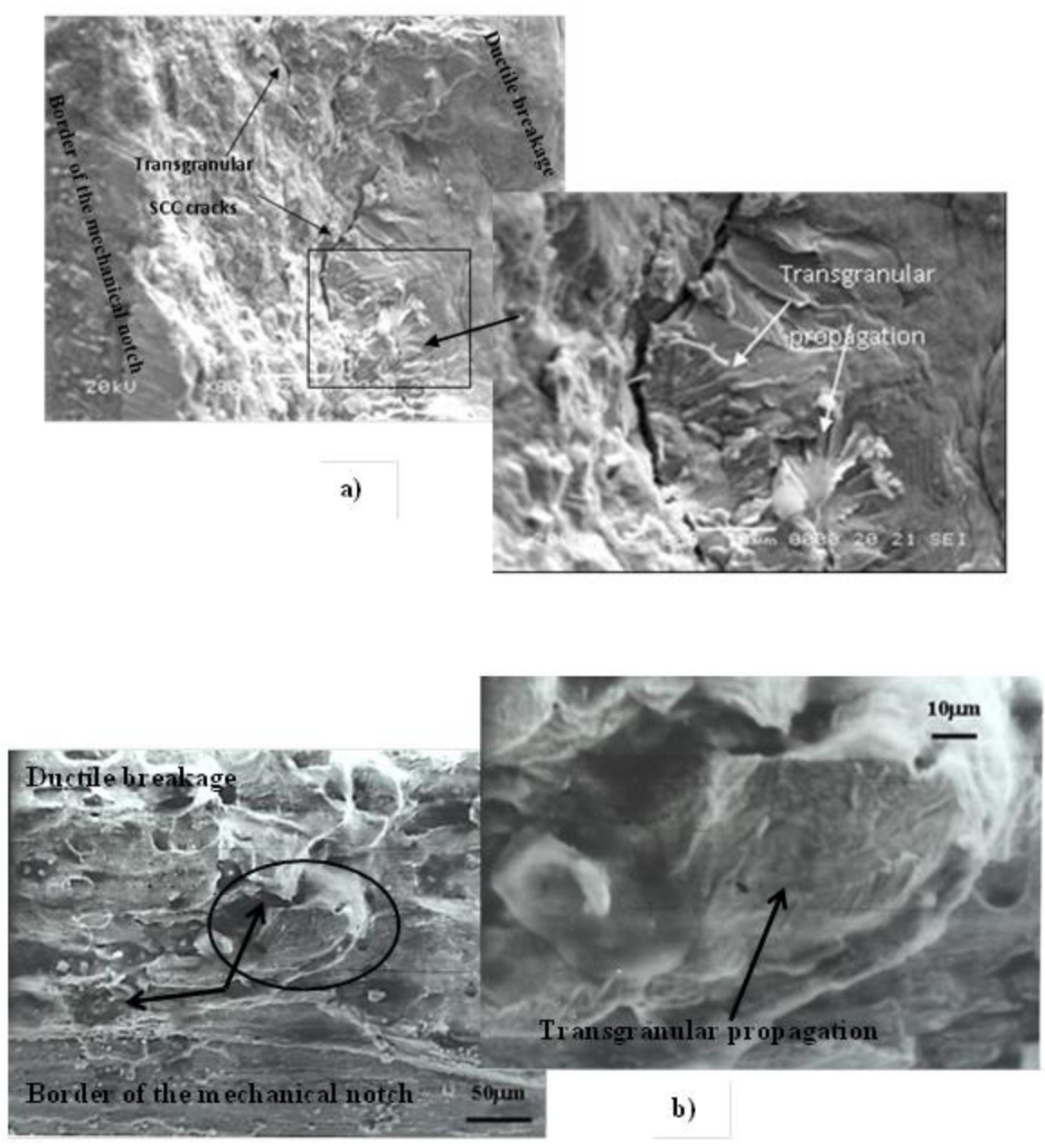

Fig. 5. SEM on the breaking surface of Incoloy 800 samples tested at $260^{\circ} \mathrm{C}$ : (a) in $10 \% \mathrm{NaOH}$; (b) in $10 \% \mathrm{NaOH}+0.33 \mathrm{~g} / \mathrm{l} \mathrm{NaCl}$
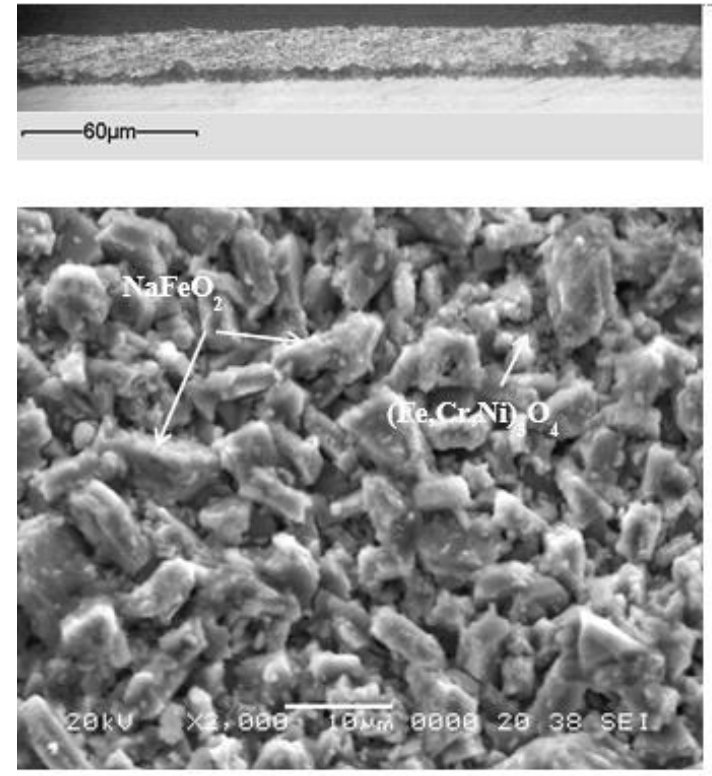

(a)
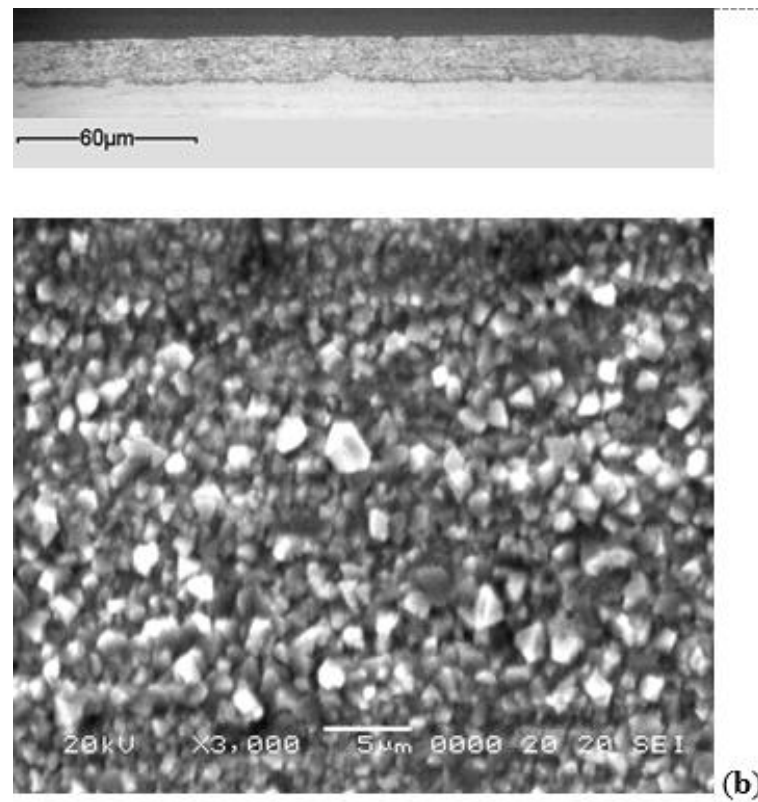

(b)

Fig. 6. Oxide layers formed on the surface of specimens after 60 days SCC tests at $260^{\circ} \mathrm{C}$ and 50 bars in: (a) $10 \% \mathrm{NaOH}$; (b) $10 \% \mathrm{NaOH}+0.33 \mathrm{~g} / \mathrm{lNaCl}$ (up - optical microscopy; down - SEM)

Considering that the oxide layer formed during the SCC tests is responsible for this behaviour at SCC in the two environments, the morphology and the composition of these oxides were investigated. From metallographic images presented in Figure 6, it may say that after 60days, the oxide layer formed in $10 \% \mathrm{NaOH}$ has approximately $4 \mu \mathrm{m}$ thickness, while oxide layer formed in $10 \% \mathrm{NaOH}+0.33 \mathrm{~g} / \mathrm{L} \mathrm{NaCl}$ is only up to $1 \mu \mathrm{m}$ thickness. From these images, the oxide layers formed in the both testing solutions appear to be adherent and compact. However, from SEM images acquired at the surface of the specimens tested in pure $10 \% \mathrm{NaOH}$, one may observe that the oxide layer is not very compact, and that they are composed by some large and elongated particles (Fig. 6a -SEM). Instead, the oxide layer 
formed at the surface of the specimens tested in $10 \% \mathrm{NaOH}+0.33 \mathrm{~g} / \mathrm{L} \mathrm{NaCl}$ appears to be compact and adherent, being formed by small and tetrahedral particles (Fig. 6b -SEM).

Table 4

CHEMICAL COMPOSITION OF OXIDE LAYER FORMED ON THE SURFACE OF SPECIMENS TESTED IN CAUSTIC ENVIRONMENT AT $260^{\circ} \mathrm{C}$, IDENTIFIED BY EDS

\begin{tabular}{|c|c|c|c|c|c|}
\hline Testing Solution & Fe (wt\%) & $\mathbf{C r}(\mathbf{w t} \%)$ & $\mathrm{Ni}(\mathbf{w t} \%)$ & $\mathrm{Na}(\mathbf{w t} \%)$ & $\mathbf{O}(\mathbf{w t} \%)$ \\
\hline $10 \% \mathrm{NaOH}$ & 35.67 & 9.44 & 5.61 & 6.36 & 42.92 \\
\hline $10 \% \mathrm{NaOH}+0.33 \mathrm{~g} / \mathrm{NaCl}^{-}-$ & 37.67 & $14.29^{-}$ & 13.92 & 0.24 & $33.88^{-}$ \\
\hline
\end{tabular}

The elemental composition obtained by EDS is presented in Table 4. On may observe that the Fe content is roughly the same in the both cases (pure caustic solution or contaminated with $\mathrm{NaCl}$ ), while the large amounts of $\mathrm{Cr}$ and $\mathrm{Ni}$ are present at the surface of the sample tested in $10 \% \mathrm{NaOH}+0.33 \mathrm{~g} / \mathrm{L} \mathrm{NaCl}$ solution comparative with the sample tested in pure alkaline solution. Based on these observations, we can say that the $\mathrm{Cr}$ and $\mathrm{Ni}$ oxides can be present in a large amount at the surface of tested specimens in the presence of $\mathrm{Cl}^{-}$ions, conferring a great resistance at SCC for Incoloy 800.

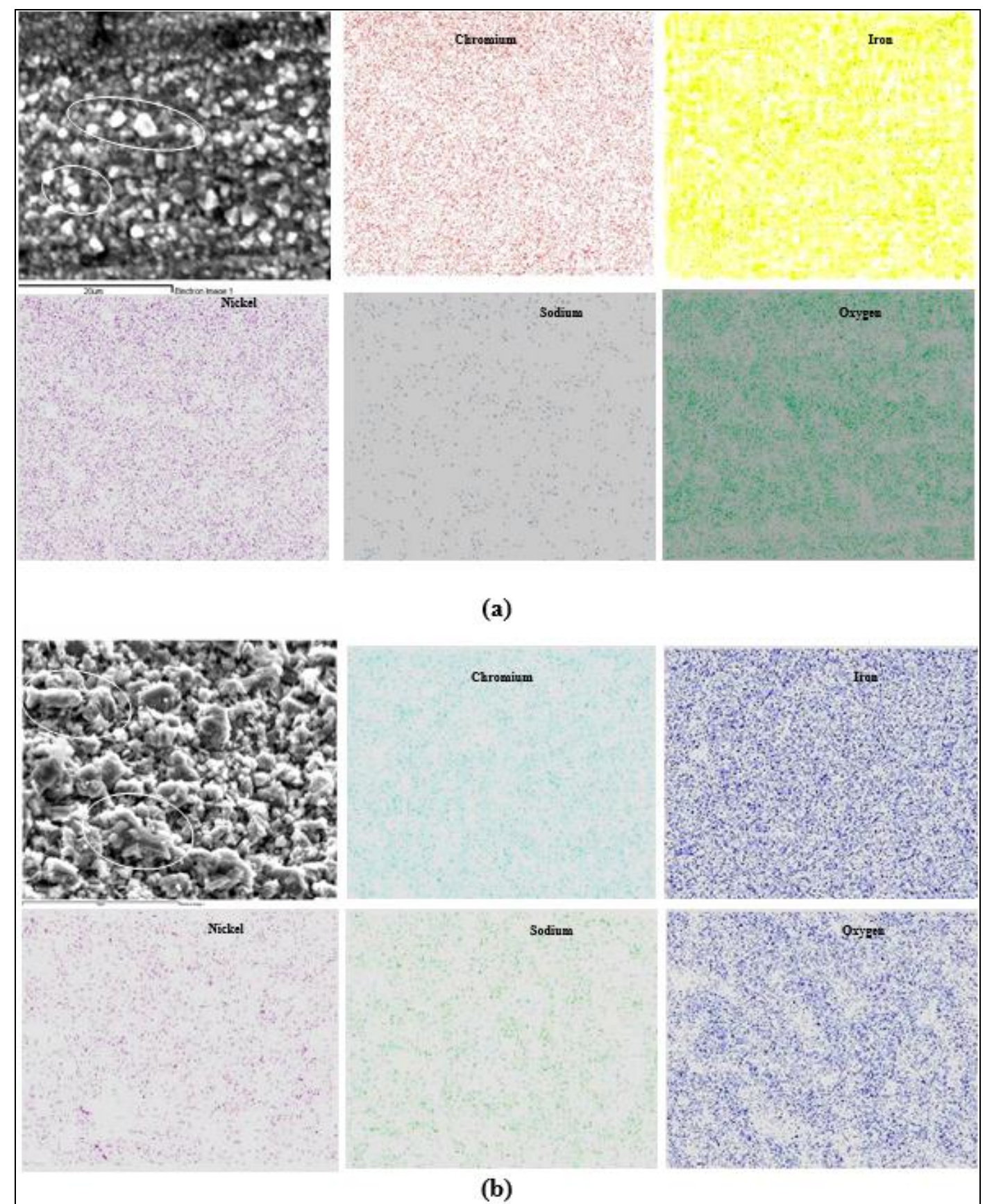

Fig. 7 Distribution maps of elements in the oxide layer formed on the specimens surface tested at $260^{\circ} \mathrm{C}$ and and 50bars in: (a) $10 \% \mathrm{NaOH}$; (b) $10 \% \mathrm{NaOH}+0.33 \mathrm{~g} / \mathrm{LnaCl}$ 
Taking into account that the sodium and oxygen are present in a higher percent in the oxide layer formed at the surface of specimen tested in pure caustic solution, we can associate the larger particles from Figure 6a (SEM) with compounds of $\mathrm{Na}, \mathrm{Fe}$ and oxygen. This affirmation is sustained by the distribution map of elements presented in Figure 7a. The elements $\mathrm{Fe}, \mathrm{Cr}$, Ni and oxygen are approximately uniform distributed in the oxide layer, but $\mathrm{Na}$ correspond to the large particle from the oxide layer. By using X-Rays diffraction, on the surface of one sample tested in $10 \% \mathrm{NaOH}$ were identified the followings compounds: $\mathrm{NiCr}_{2} \mathrm{O}_{4}, \mathrm{Fe}_{3} \mathrm{O}_{4}, \mathrm{NaFeO}_{2}$ and $\mathrm{FeCr}_{2} \mathrm{O}_{4}$. Therefore, we can state that the large and elongated particles present at the external side of the oxide layer (Figure 6a-SEM) correspond to the $\mathrm{NaFeO}_{2}$ compound. Under this external layer there is an inner layer formed by small and round particles, corresponding to the spinelic compound type $\left(\mathrm{Fe}, \mathrm{Cr}, \mathrm{Ni}_{3} \mathrm{O}_{4}\right.$ (Fig. 6a -SEM).

In the case of specimen exposed in caustic solution contaminated with $\mathrm{Cl}^{-}$, distribution maps of elements show a uniform distribution of elements. However, it may observe the absence of $\mathrm{Cr}$ and $\mathrm{Ni}$ in the zones corresponding to the bigger particles (Fig.7b). This means that these particles correspond only to the iron oxides. The compounds identified by $\mathrm{XRD}$ were $\mathrm{NiCr}_{2} \mathrm{O}_{4}, \mathrm{Fe}_{3} \mathrm{O}_{4}, \mathrm{NaFeCl}_{4}$, and $\mathrm{Na}_{4} \mathrm{CrO}_{4}$. Taking into account the shape and dimensions of oxides particles, we can say that the biggest ones represent magnetite crystals (Fig. 6b), while the compact and smaller particles represent the spinelic compounds of magnetite type, enriched in $\mathrm{Cr}$ and $\mathrm{Ni}$ 00. The studies on the corrosion kinetics of Incoloy 800 in alkaline environment showed that the release rate of the corrosion products decrease with the increasing of temperature and solution $\mathrm{pH}$, which can be explained by the small solubility of magnetite at higher $\mathrm{pH}$ values 0 . This means that the spinelic oxides of magnetite type form adherent deposits in the testing conditions.

\section{Conclusions}

The paper investigates the SCC behaviour of Incoloy 800 in pure caustic or contaminated with chlorine ions environment $(10 \% \mathrm{NaOH}$ and $10 \% \mathrm{NaOH}+0.33 \mathrm{~g} / \mathrm{L} \mathrm{NaCl})$ that can be formed in area with restrictive flow in the secondary side of CANDU steam generators.

It was noticed that the addition of $0.33 \mathrm{~g} / \mathrm{L} \mathrm{NaCl}$ in $10 \% \mathrm{NaOH}$ solution lead to the decreasing of the corrosion rate and corrosion current, while the corrosion potential shifts towards the electronegative range.

The SCC tests in autoclaves emphasised that the SCC susceptibility of Incoloy 800 is higher in pure caustic solution compared to the caustic solutions contaminated with chlorine ions. In the pure caustic solution, the SCC cracks propagated in the tube wall thickness up to $120 \mu \mathrm{m}$. The initiation and propagation steps are transgranular. The features of the transgranular propagation of SCC cracks, characteristic to the austenitic alloys in the caustic environment, it was noticed.

In the presence of chlorine ions, the SCC cracks are initiated only from pits and the observed penetration depth was not more than $20 \mu \mathrm{m}$. This behaviour can be explained by the fact that, in the presence of chlorine ions, the building rate of protective layer, rich in $\mathrm{NiCr}_{2} \mathrm{O}_{4}$, is very high and the stress state at the crack tip, needed to break the oxide film with an enough frequency so that the crack can propagate rapidly, is not fulfilled. Also, in the presence of chlorine ions, the SCC cracks are initiated only from pits. The presence of pits leads to the local relaxation of the stress, therefore the value of the stress threshold over which the SCC cracks propagate is not reached.

Taking into account the experimental results, it can say that the priming of cracks in existing pits can be the main mechanism for initiating SCC cracks on the secondary circuit side, under specific conditions of operation of CANDU steam generators.

\section{References}

1.BERGE PH., DONATI J. R., PRIUX B., VILLARD D., Corrosion, 33, No12, 1977, pp. 425

2.GONZALES F., SPEKKENS P., Nuclear Journal of Canada, No1-2, 1986, pp. 129.

3.WANG R.C., PAN C., TSAI C.H., Nuclear Technology, 94, No 1, 1991, pp. 1

4.GARAUD Y.S. Issues and Modelling Concepts for Assessment of Local Corrosion on the Secondary Side of Steam Generators. Int. Conf. Control of Corrosion on the Secondary Side of Steam Generator, Proceeding of Improving the Understanding and Control of the Secondary Side of Steam Generators, Airlie, USA, 1995.

5.***SR EN ISO 7539-5 Corrosion of Metals and Alloys. Stress Corrosion Testing, Part 5 - Preparation and Use of C-ring Specimens, 1996

6.KAWAMURA H., HIRANO H., KOIKE M., SUDA M., Corrosion, 58, No 1, 2002, pp. 941

7.DINU A., FULGER M., IONESCU D., VELCIU L., RADULESCU M., NT\&RP,XX, No1, 2005, pp.74

8.DINU A., VELCIU L., CHICINAS I., IONESCU D, JNRD, 3, 2012, pp. 41

9.AIREY G.P., VAIA A.R., ASPDEN R.G., Nuclear Technology, 55, No 2, 1981, pp. 436

10.ZOTICĂ D., Cernavoda NPP - Boiler and Steam Cycle Chemistry Control, $5^{\text {th }}$ International Seminar on Primary and Secondary Side Water Chemistry of NPPs, Eger, Hungary, 2001

11.SAITO N., SAKAMOTO H., SUGIMOTO K., Corrosion, 54, No 9, 1998, pp. 700

12.COMBRADE P., Cap. 10. Corrosion sous contrainte et fatigue-corrosion. In Les aciers inoxydables, First ed. Lacombe, P. ; Baroux, B.; Beranger G. Les Editions de Physique, Paris, France, 1990, pp. 333

13. KIM A.J., Corrosion, 51, No 11, 1995 pp. 849

14.KIM A.J., Corrosion, 55, No 1, 1999, pp. 81

15.DINU A., MINCU M., STANCIULESCU M., DINIASI D., JNRD, 10, 2015, pp. 39

16.IGLESIAS. M., CALDERON R., Nucl.Eng.Des., 219, 2003, pp. 1

17.LUCAN D., Nucl.Eng.Des., 4, 2011, pp. 1172

Manuscript received: 30.03 .2019 
